J. Clin. Chem. Clin. Biochem.

Vol. 20, 1982, pp. 575-580

\title{
The Determination of Spinal Fluid Protein: An Attempt at Standardization
}

\author{
By B. G. Blijenberg
}

Dept. of Clinical Chemistry, Academic Hospital Rotterdam,

\section{E. A. H. Hische}

Dept. of Neurology, Academic Hospital Amsterdam,

\section{H. H. Kamp}

Dept. of Neurology, Academic Hospital Utrecht,

\author{
K. J. B. Lamers
}

Dept. of Neurology, Academic Hospital Nijmegen and

\section{J. H. M. Souverijn}

Dept. of Clinical Chemistry, Academic Hospital Leiden

(Received December 22, 1981/April 26, 1982)

Summary: A working group of five laboratories cooperated in the Netherlands with the aim of proposing a useful and well standardized method for the determination of total protein in cerebrospinal fluid. A survey model was used as a basis for the discussion of the practical work. The biuret technique was chosen; representing a modification of the selected method for serum.

\section{Die Bestimmung von Protein im Liquor: Versuch einer Standardisierung}

Żusammenfassung: Eine Arbeitsgruppe aus̃ füf Laboratorien in den Niederlanden arbeitete mit dem Ziel zusammen, eine brauchbare und gut standardisierte Methode zur Bestimmung des Gesamt.Proteins im Liquor cerebrospinalis vorzuschlagen. Als Basis für die Diskusssion der praktischen Arbeit wụ̂rde ein Ringversuchsmodell benutzt. Das Biuretverfahren wurde gewählt; es ișt eine Modifikation der für Serum añgenommenen ,Selected Method“ zur Proteinbestimmung in Liquorproben.

\section{Introduction}

Since the pioneering work of $K a f k a$, in the twenties and thirties, on the significance of the determination of protein in cerebrospinal fluid, many articles have been written on this subject (1). Even now, in our opinion, Rice's statement in 1965 is still true (2).

"At present there is no highly accurate and precise procedure available for the determination of total proteins in cerebrospinal fluid (CSF) ideally suitable for routine use in a hospițal clinical laboratory."

Nevertheless, the invitation of the Dutch Multiple Sclerosis Foundation to give recommendations on the standardization of CSF protein examinations was accepted by a working group of five laboratories. These laboratories were chosen because of their experience with the subject and/or because of their daily workload (10-20 samples CSF per day). In this article only work on the determination of total proteins is reported. However, attempts to standardize the electrophoresis of CSF and the determinations of albumin and $\gamma$-globulins are also being discussed in the Netherlands.

As a compromise between all published methods, Kjeldahl, turbidimetric, nephelometric, biuret, dyebinding, Lowry and so on, two approaches were chosen i.e. the dye-binding technique with Coomassie Blue and a modification of the biuret technique. The first because of its simplicity and its sensitivity, as well as its growing 
popularity $(3,4)$, the second because of its possible connection with the selected method for serum analysis $(6,7)$. In the biuret procedure it was decided to use exactly the same reagents as with the serum method; owing to the low protein level in CSF, it was necessary to add a concentration step.

\section{Materials and Methods}

Materials (p.a. quality)

1. Reagents biuret technique serum: see Doumas $(6,16)$.

2. Reagents biuret technique CSF; see reagents $1 ., 3$., and 4.

3. Trichloroacetic acid (Merck), $100 \mathrm{~g} / \mathrm{l}$.

4. Phosphotungstic acid (Merck), $25 \mathrm{~g}$ in $1 \mathrm{~mol} / 1 \mathrm{H}_{2} \mathrm{SO}_{4}(\mathrm{H})$

5. Sodium hydroxide (Merck), $100 \mathrm{~g} / 1$.

6. Human albumin, purified (Hoechst - Behringwerke AG).

7. Gamma globulins (Central Laboratory The Netherlands

Red Cross Blood Transfusion Service), $160 \mathrm{~g} / \mathrm{l}$.

Methods

1. Routine methods participating laboratories

a. Laboratory A: modified Lowry method described by Rieder (8).

b. Laboratory L: \amido black absorption method described by Schaffner et al. (9).

c. Laboratory N: automated, home-made, modification Lowry technique.

d. Laboratory R: modified Lowry method described by Papadopoulos (10).

e. Laboratory U: trichloroacetic acid turbidity technique (11).

\section{Methods also used in the surveys}

a. Bradford technique (3).

b. Rieder technique (8).

c. Pierce technique: Pierce Rapid Stat ${ }^{\circledR}$ Kit Microprotein, product no. 45700 .

d. Biuret technique, see below

\section{Recommended method spinal fluid}

a. Sample

To $1.0 \mathrm{ml}$ of spinal fluid $1.0 \mathrm{ml}$ of deproteinizing agent (trichloroacetic acid or phosphotungstic acid) is added. After mixing and standing for 10 minutes the sample is centrifuged at $3000 \mathrm{~min}^{-1}$ for 10 minutes. After decanting the supernatant the precipitate is blotted carefully with filter paper and dissolved in $0.1 \mathrm{ml}$ of $\mathrm{NaOH}(100 \mathrm{~g} / \mathrm{l})$. Then $2.0 \mathrm{ml}$ of biuret reagent is added, after mixing and incubation for $\mathbf{3 0}$ minutes, the absorbance of the sample is read in a spectrophotometer at $540 \mathrm{~nm}$ against the reagent blank.

b. Reagent blank

Saline is used instead of spinal fluid.

c. Sample blank

In case of xanthochromia a sample blank has to be measured according to Doumas.

In normal colourless samples this blank can be neglected.

4. Total protein determination in serum: see Doumas et al. $(6,16)$.

Results

As mentioned in the Introduction a Coomassie Blue and a biuret procedure were chosen. However, the project was not started that way. After lengthy discussions on the advantages and the disadvantages of the various methods it was decided to organize the study with the help of surveys. A first survey was organized to become acquainted with the model of study and to give a practical basis for discussion.

The following methods were included:

a) the routine method of the participating laboratory;

b) the Coomassie Blue method according to Bradford;

c) the Coomassie Blue method by means of a commercial kit (Pierce);

d) a procedure based on the Lowry technique as described by Rieder;

e) a biuret technique adapted to spinal fluid.

All laboratories were asked to gain experience with two or three methods not or partially known before the survey started. Without mentioning the results it can be said that the general opinion afterwards was negative with the respect to the Bradford and the Rieder technique. The Bradford method showed poor colour stability, and the Rieder procedure (in our opinion the method with the most "selected method capacities") was felt to be somewhat cumbersome, as well as giving different colour yields for the various protein fractions (5).

The results obtained with the Pierce kit and the biuret technique looked promising. Therefore, it was decided to concentrate more on our biuret modification in a second survey. In this survey we combined the analysis of serum samples with the selected biuret method with the analysis of 100 and 200 -fold salina dilutions of these sera with the "micro" biuret technique. In addition, several spinal fluid samples were analyzed.

All specimens (included standards) came from one central point. As a second comparison we all used the Pierce kit for the serum dilutions. This survey was conclusive. Our choice was made for the biuret procedure. In the third and final survey, therefore, we used all the experience obtained with the forgoing surveys. In this experiment the routine methods of all participating laboratories i.e. the state of the art, were compared with the biuret technique as well as the Coomassie Blue procedure. We analysed six spinal fluid samples, five diluted serum samples and six diluted commercial sera. The results are shown in table 1.

Furthermore the comparability between the serum and CSF biuret methods as well as the transferability of the CSF procedure were tested by analysing 10-20 sera, diluted and undiluted. This was done by all participating laboratories separately. In figure 1 the results of the serum analyses are given on the $\mathbf{x}$-axis (recalculated on the basis of the saline dilution): The $y$-axis shows the measured values.

The overall impression of the CSF biuret technique, as can be seen in figure 1 and table 1 was encouraging, so we continued by studying several aspects of the method i.e. calibration, precision, matrix effects and protein concentration.
.6 


\section{Calibration}

The preparation of the standard in the serum determination has been published in detail $(6,7)$. We followed the same procedure with one extra step, i.e. dilution with saline. Because of the special role $\gamma$-globulins may play in the CSF of multiple sclerosis patients, attention was paid to albumin-globulin based standards. In figure 2 the results of some mixtures are given.

Because it is easier to handle and because of the small differences between albumin standards and the albuminglobulin mixtures (fig. 2) we chose a standard based on human albumin only. In an attempt to confirm the correctness of this decision a number of serum specimens with elevated $\gamma$-globulin fractions was analysed. This was done in the same way as mentioned earlier (fig. 1).

The results proved to be highly comparable with the results given in figure 1 .

The linearity of the calibration graph was not studied in detail. However, a straight line was found up to $2000 \mathrm{mg} / 1$.

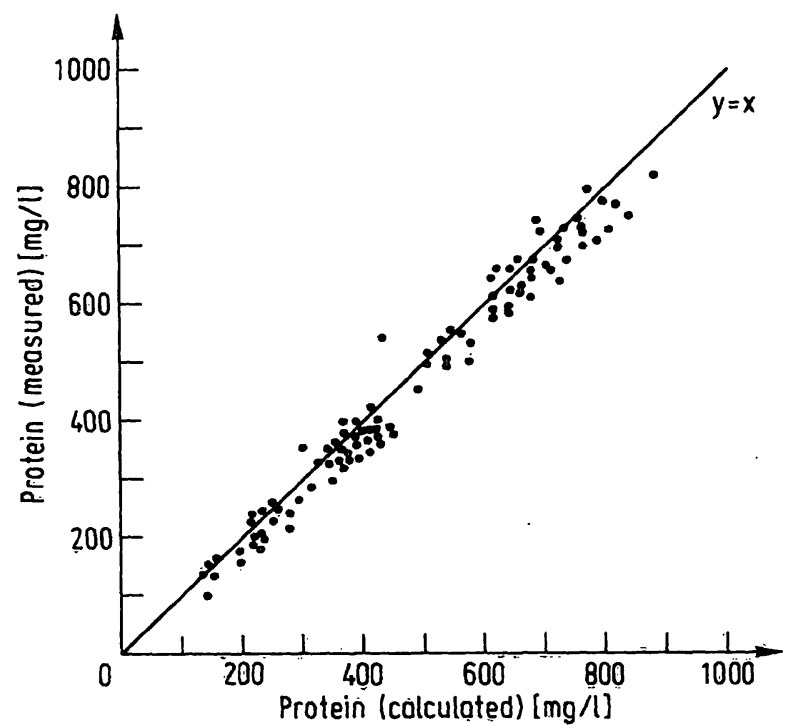

Fig. 1. Comparison of calculated vs. measured protein values. Calculated: measurement of serum samples (see Methods) and dilutions with saline.

Measured: measurement of dilutions (see Methods) after precipitation with trichloroacetic acid y (measured) = $0.99 \times$ (calculated) -9 .

$\mathrm{n}=142 \mathrm{r}=0.99 \quad \overline{\mathrm{x}}=485 \mathrm{mg} / \mathrm{l} \quad \overline{\mathrm{y}}=470 \mathrm{mg} / \mathrm{l}$

\section{Precision}

The within-run precision for the CSF biuret technique was determined at three different levels i.e. a high, low and middle value, while the day-to-day precision was estimated at one level (middle value). The data are shown in table 2.

\section{Matrix effects}

To determine whether the foregoing results, in most cases obtained with saline diluted serum and diluted
Tab. 1. Results of survey 3. For a description of all the methods used: see Methods section. Dilutions of serum samples made with saline.

\begin{tabular}{|c|c|c|c|c|c|c|}
\hline \multirow[t]{2}{*}{ Sample } & \multicolumn{2}{|c|}{$\begin{array}{l}\text { Routine } \\
\text { method }\end{array}$} & \multicolumn{2}{|c|}{$\begin{array}{l}\text { Pierce } \\
\text { method }\end{array}$} & \multicolumn{2}{|l|}{$\begin{array}{l}\text { Biuret } \\
\text { method }\end{array}$} \\
\hline & $\begin{array}{l}\bar{x} \\
(\mathrm{mg} / \mathrm{l})\end{array}$ & $\begin{array}{l}\text { C.V. } \\
\text { (\%) }\end{array}$ & $\begin{array}{l}\bar{x} \\
(\mathrm{mg} / \mathrm{l})\end{array}$ & $\begin{array}{l}\text { C.V. } \\
(\%)\end{array}$ & $\begin{array}{l}\bar{x} \\
(\mathrm{mg} / \mathrm{l})\end{array}$ & $\begin{array}{l}\text { C.V. } \\
(\%)\end{array}$ \\
\hline
\end{tabular}

Spinal fluid

$\begin{array}{rrrrrrr}1 & 186 & 31.5 & 130 & 18.6 & 175 & 16.8 \\ 2 & 267 & 23.7 & 201 & 11.6 & 249 & 5.0 \\ 3 & 357 & 17.9 & 300 & 6.1 & 336 & 4.9 \\ 4 & 432 & 16.9 & 386 & 8.3 & 433 & 4.4 \\ 5 & 598 & 12.8 & 561 & 3.5 & 589 & 3.1 \\ 6 & 714 & 9.8 & 682 & 1.7 & 757 & 6.3\end{array}$

Diluted serum

(human)

$\begin{array}{rrrrrrr}1 & 696 & 16.1 & 666 & 9.2 & 704 & 7.3 \\ 2 & 347 & 9.4 & 311 & 8.8 & 344 & 5.6 \\ 3 & 224 & 8.8 & 188 & 14.0 & 230 & 8.1 \\ 4 & 655 & 18.0 & 668 & 9.0 & 719 & 5.0 \\ 5 & 339 & 14.0 & 324 & 9.1 & 357 & 5.6\end{array}$

Diluted serum

(commercial)

\begin{tabular}{rrrrrrr}
1 & 468 & 19.4 & 448 & 10.5 & 517 & 8.1 \\
2 & 715 & 13.6 & 681 & 5.7 & 697 & 3.5 \\
3 & 708 & 20.6 & 579 & 5.1 & 666 & 3.8 \\
4 & 708 & 9.6 & 782 & 2.7 & 694 & 3.1 \\
5 & 631 & 10.6 & 606 & 3.8 & 642 & 4.0 \\
6 & 554 & 11.8 & 514 & 5.4 & 570 & 3.5 \\
\hline
\end{tabular}

Tab. 2. Precision data. The data represent the precision of one laboratory.

\begin{tabular}{|c|c|c|c|}
\hline $\begin{array}{l}\text { Within-run } \\
\mathrm{n}=20 \\
\overline{\mathrm{x}} \\
(\mathrm{mg} / \mathrm{l})\end{array}$ & $\begin{array}{l}\text { C.V. } \\
(\%)\end{array}$ & $\begin{array}{l}\text { Day-to-day } \\
\mathrm{n}=20 \\
\overline{\mathrm{x}} \\
(\mathrm{mg} / \mathrm{l})\end{array}$ & $\begin{array}{l}\text { C.V. } \\
\text { (\%) }\end{array}$ \\
\hline $\begin{array}{l}230 \\
400 \\
600\end{array}$ & $\begin{array}{l}4.2 \\
2.2 \\
1.8\end{array}$ & 400 & 2.2 \\
\hline
\end{tabular}

Tab. 3. Comparability CSF vs. diluted serum $1: 2$ mixtures CSF (L), diluted serum (S) and albumin standard (A). Duplicate measurements from one laboratory. Value $S$ known by applying serum biuret procedure, value $A$ known from weighing (both including dilution factor).

\begin{tabular}{llll}
\hline Sample & $\begin{array}{l}\text { Measured } \\
(\mathrm{mg} / \mathrm{l})\end{array}$ & $\begin{array}{l}\text { Calculated } \\
(\mathrm{mg} / \mathrm{l})\end{array}$ & $\begin{array}{l}\text { Difference } \\
(\mathrm{mg} / \mathrm{l})\end{array}$ \\
\hline L1 & 368 & & \\
L2 & 575 & & \\
L3 & 516 & & \\
L4 & 418 & & \\
L5 & 210 & 349 & -12 \\
L1 + S & 337 & 453 & +2 \\
L2 + S & 455 & 423 & +20 \\
L3 + S & 443 & 374 & -24 \\
L4 + S & 350 & 290 & 0 \\
L5 + S & 290 & 432 & -2 \\
L1 + A & 430 & 536 & +4 \\
L2 + A & 540 & 506 & +2 \\
L3 A & 508 & 457 & +10 \\
L4 + A & 467 & 354 & -10 \\
L5 + A & 344 & 413 & +5 \\
A + S. & 418 & & \\
A & 495 & & \\
S & 330 & & \\
\hline
\end{tabular}


human albumin samples, were compatible with spinal fluid specimens, five different CSF samples were diluted $(1: 2)$ with an arbitrarily chosen serum sample and a standard.

The data are given in table 3 .

As a second approach to the study of the matrix effects of diluted serum in comparison with spinal fluid, three different serum specimens were diluted and analyzed.

The slopes of these lines are shown in figure 3.

\section{Protein concentration}

Trichloroacetic acid as deproteinizing agent is well known in clinical chemistry. Therefore it was also chosen in this study. We checked the effect of two different concentrations (100 and $200 \mathrm{~g} / \mathrm{l}$ ) as well as the effect of boiling of the mixture. We could detect no differences. However, in the dilution graphs mentioned above (figs. 1 and 2) the results measured were generally slightly lower than the results "calculated". In addition, the absorbance values of the standards seem somewhat lower than the values calculated on the basis of the serum procedure (see under Discussion). Some of us even found an intersection of the $\mathrm{x}$-axis.

We decided to follow the suggestion of Bürgi et al. who used phosphotungstic acid as a protein precipitant (12). Because of the "higher" calibration graph obtained with phosphotungstic acid we found it worthwhile to repeat the experiment described in figure 1 . The results are shown in figure 4:

Furthermore the trichloroacetic acid and the phosphotungstic acid modification were compared. These results are given in figure 5.

\section{Discussion}

In an attempt to recommend a spinal fluid protein determination which could meet certain standardization criteria we studied various possibilities.

As a basis of this study the survey model was chosen because of the distance between the cooperating laboratories (up to $150 \mathrm{~km}$ ). With the help of this model several determinations as well as several aspects of these determinations were studied.

As a result of all discussions and practical work two methods were chosen i.e. a dye-binding technique with Coomassie Blue and a modification of the biuret technique. We did not study the Coomassie Blue procedure $(3,4)$ in great detail, with the exception of one of us (E. A. H.); it was only chosen because of its easiness of operation especially with the commercial kit. A drawback of the method is the different weight of the various proteins in the colour reaction (13). Moreover, recommendation of "our" Coomassie Blue procedure would have been blocked, as the reagents are now protected by patent law.

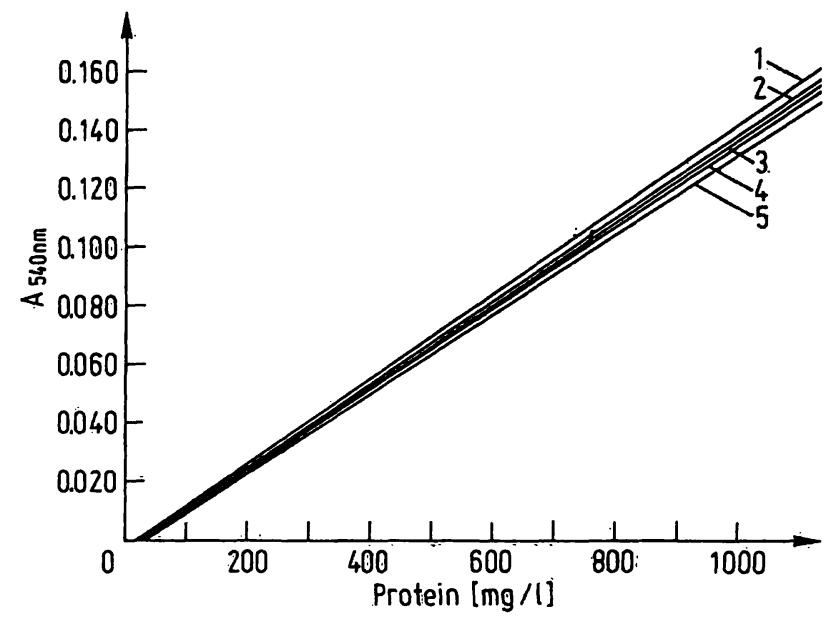

Fig. 2. Calibration graphs with albumin and albụmin $-\gamma-g l o b u l i n$ mixtures. Saline dilutions from albumin $(50 \mathrm{~g} / 1)$ and $\gamma$-globulin $(47 \mathrm{~g} / \mathrm{l})$.

$1=$ albumin $2=$ albumin-globulin $(4+1) \quad 3=$ albumin globulin $(1+1) \quad 4=$ albumin-globulin $(1+4) \quad 5=$ globulin.

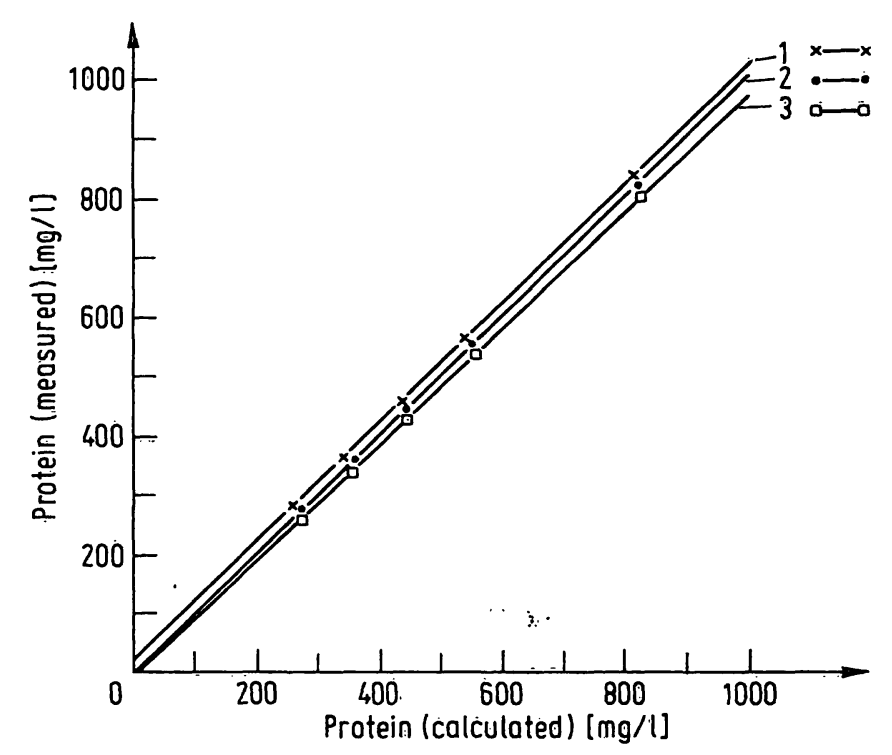

Fig. 3. Saline dilutions of three different patient sera.

Therefore, we concentrated on a determination based on the well known biuret reaction i.e. the procedure recommended by the National Clinical Chemistry Laboratory Standardization (NCCLS) Committee and also by the Dutch Standardization Committee for Clinical Chemistry. This procedure is only described for serum or plasma. Thus, a "translation" to spinal fluid was needed. This was done by introducing a protein concentration step. The suitability of our CSF biuret modification is shown by figure 1 and table 1 . In fact, figure 1 is a combination of the transferability of the serum procedure to a spinal fluid procedure as well as a proof of the high precision which can be obtained in both cases. In this case, all participants were left free with respect to the reagent preparation and the choice of the samples. It is even remarkable that the precision; is better than the 


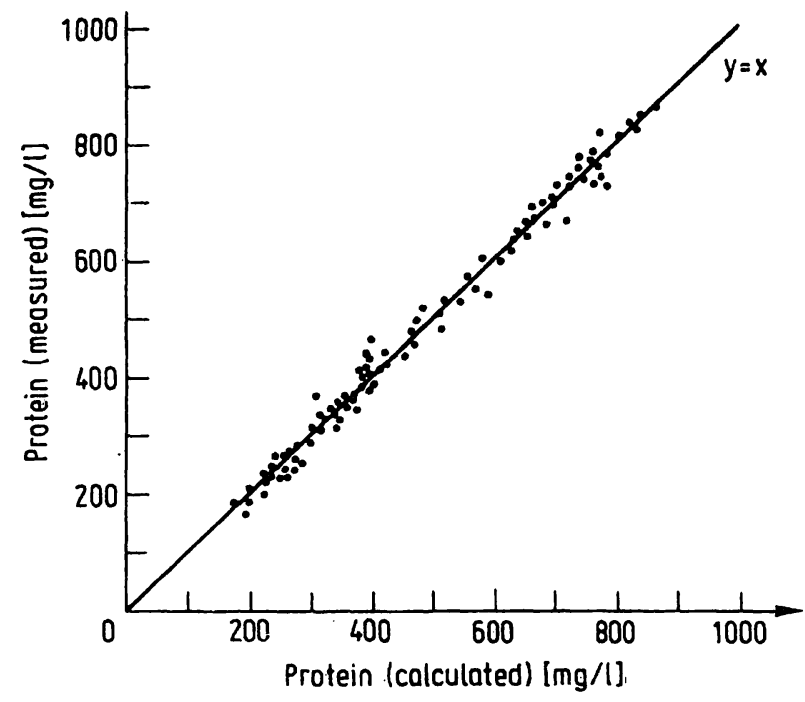

Fig. 4. Comparison of calculated vs. measured protein values. Calculated: measurement of serum samples (see Methods) and dilutions with saline.

Measured: measurement of dilutions (see Methods) after precipitation with phosphotungstic acid.

$y$ (measured) $=0.98 \times$ (calculated $)+4 n=116 \quad r=0.99$ $\bar{x}=503 \mathrm{mg} / \mathrm{l} \quad \bar{y}=500 \mathrm{mg} / 1$

precision we obtained with a simple technique like the Coomassie Blue technique (see tab. 1). Table 1 is rather embarassing when the actual situation is considered. It shows the need for improvement very convincingly.

An answer to the question of accuracy and precision of a CSF protein determination is very difficult. However, a comparison between the state of the art, now and possibly in the future, strongly favours the biuret technique, or at least a standardization against this technique.

From figure 3 and table 3 it is chlear that diluted serum was a good substitute for spinal fluid in our experiments.

The experiments described under Results (protein concentration) will possibly give a tool for a description of the calibrating solution as well as a proof of the correctness of the protein concentration step to be chosen. In. the selected method for total proteins in serum used in The Netherlands an absorbance of $0.287-0.293$ is accepted for the standard human albumin solution of $50 \mathrm{~g} / 1$ (sample volume $0.1 \mathrm{ml}$, end volume $5.1 \mathrm{ml}$ ) (see also Doumas (16)). Assuming a volume of $0.1 \mathrm{ml}$ for the proteins precipitated in the CSF procedure described under Materials and Methods one can calculate that this means for a CSF-albumin standard of $500 \mathrm{mg} / \mathrm{l}$ $0.066-0.070$ absorbance units. This figure, which was found in practice, favours the deproteinization with phosphotungstic acid (see fig. 2). The correctness of this statement is further demonstrated by figures 4 and 5 .

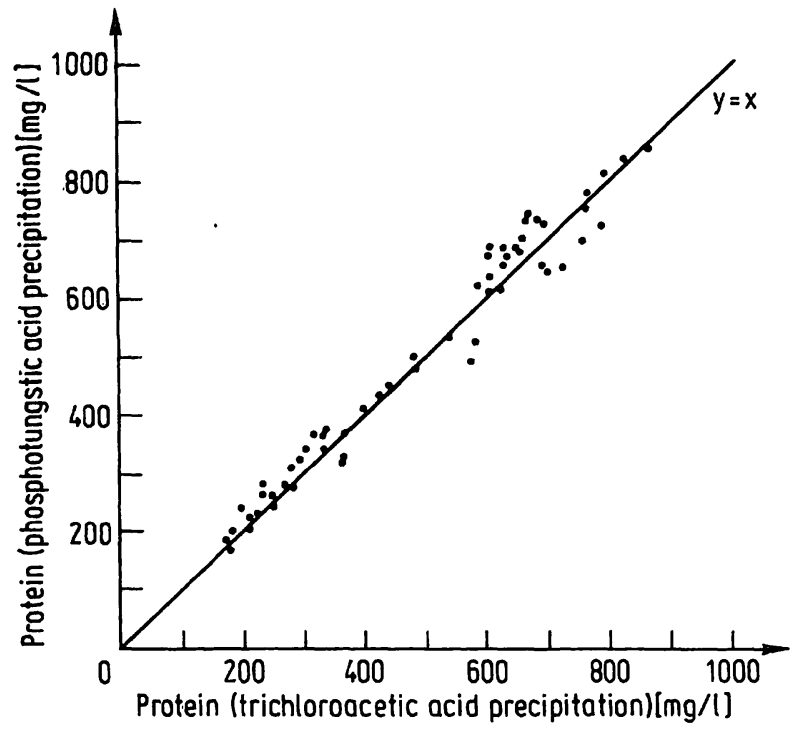

Fig. 5. Comparison of measurements of diluted serum samples $x$-axis: trichloroacetic acid precipitation $y$-axis: phosphotungstic acid precipitation $y=0.99 x+16 \quad n=62 \quad x=0.98 \quad \bar{x}=468 \mathrm{mg} / \mathrm{l}$ $\overline{\mathrm{y}}=482 \mathrm{mg} / \mathrm{l}$

With the data shown in the tables and in the figures, one can enquire as to the practical utility of this study. In our opinion two approaches can be chosen i.e.

1) to use the method described in daily routine or

2) to use it as a selected method for the determination of total proteins in cerebrospinal fluid.

With respect to the first possibility, it is felt that the absorbance of the biuret colour in the CSF is rather low i.e. $0.030-0.080$ absorbance units in the reference range.

Furthermore, the sample volume we used is rather high $(1.0 \mathrm{ml})$. Although we feel that these disadvantages can be minimized by using a high quality spectrophotometer and by taking lower sample volumes, we are of the opinion that the second approach is more useful. In this approach the sample volume is less important. Moreover, it is self-evident that a high performance spectrophotometer must be used. And of course, the application of a selected method does necessitate special care at every stage.

Therefore, with respect to the second approach the close agreement in methodology in serum and spinal fluid assays is, in our opinion, a very striking feature. Therefore, in spite of all other recommended methods (e.g. 1.c. (14) and 1.c. (15)), we propose this study as a basis for the description of the selected method for the determination of CSF total proteins.

\section{Acknowledgement}

All technical help is gratefully acknowledged. Furthermore, thanks are due to Miss $H$. A. Roetering for organizing the surveys and to Dr. F. A.J.T.M. van den Berg for stimulating discussions in the preliminary phase. 


\section{References}

1. Schmidt, R. M. (1968) Der Liquor cerebrospinalis, p. 183, VEB Verlag Volk und Gesundheit, Berlin.

2. Rice, E. W. (1965) Stand. Methods Clin. Chem. 5, 231.

3. Bradford, M. M. (1976) Anal. Biochem. 79, 248-254.

4. Johnson, J. A. \& Lott, J. A. (1978) Clin. Chem. 24, 1931-1933.

5. Peters, T. (1968) Clin. Chem. 14, 1147-1159.

6. Doumas, B. T. (1975) Clin. Chem. 21, 1159-1166.

7. Nat. Comm. Clin. Lab. Stand. (NCCLS), Approved Standard, ASC-1 (1979).

8. Rieder, H. P. (1966) Klin. Wochenschr. 44, 1036-1040.

9. Schaffner, W. \& Weissmann, C. (1973) Anal. Biochem. $56,502-514$.
10. Papadopoulos, N. M., Hess, W. C., O'Doherty, D. \& MeLane, J. E. (1959) Clin. Chem. 5, 569-574.

11. Meulemans, O. (1960) Clin. Chim. Acta 5, 757-761,

12. Bürgi, W. \& Kaufmann, H. (1974) Schiweiz. Med. Wochenschr. 104, 1720-1724.

13. Van Wilgenburg, M. G. M., Werkman, E. M A., Van Gorkom, W. H. \& Soons, J. B. J. (1981) J. Clin. Chem. Clin. Biochem. 19, 301-304.

14. Peterson, G. (1979) Anal. Biochem. 100, 201-220.

15. Karlsson, B. \& Alling, C. (1980) Clin. Chim. Acta 105, 65-73.

16. Doumas, B. T., Bayse, D. D., Carter, R. J., Peters, T. \& Schaffer, R. (1981) Clin. Chem. 27, 1642-1650.
Dr. B. G. Blijênberg

Academic Hospital Rotterdam

Dept. of Clinical Chemistry

Dr. Molewaterplein 40

NL-3015 GD Rotterdam 